\title{
Edukasi dan Pelatihan Menjaga Kesehatan Reproduksi Remaja Putri dengan Ramuan Tradisional
}

\author{
Hadi Barru Hakam Fajar Siddiq, Diyan Ajeng Rossetyowati \\ Akademi Farmasi Jember \\ hakamfajar@gmail.com
}

\begin{abstract}
Abstrak
Kegiatan pengabdian kepada masyarakat yang dilakukan oleh dosen dari Program Studi Diploma III Farmasi Akademi Farmasi Jember yang dilaksanakan mulai tanggal 5 Februari 2017, bertempat di MTs. dan MA. Habiburrahman Desa Jatian, Pakusari Jember ini memberikan manfaat bagi siswi dalam hal menjaga kesehatan reproduksi. MTs. dan MA. Habiburrahman merupakan salah satu lembaga pendidikan tingkat pertama dan tingkat atas di bawah Departemen Agama yang berada di Desa Jatian, Kecamatan Pakusari Jember. MTs. dan MA. Habibirrahman juga memiliki lembaga pendidikan agama yaitu Pondok Pesantren Habibirrahman. Hampir 90 \% siswa dan siswi MTs. dan MA. Habiburrahman adalah santri pondok. Siswa ditingkat MTs. dan MA. memiliki rentang usia 13-17 tahun yang tergolong usia remaja. Hasil kegiatan menunjukkan bahwa pengetahuan siswi MTs dan MA Habiburrahman tentang cara menjaga kesehatan reproduksi berada dalam kategori yang sangat baik. Namun, ditinjau dari perilaku siswi terhadap pemakain sabun pembersih atau sabun sirih untuk membersihkan daerah kewanitaan menunjukkan hasil yang kurang baik. Sebanyak 22 orang siswi MA dan 24 siswi MTs atau sekitar 84\% siswi MA dan 46\% siswi MTs tidak pernah membersihkan daerah kewanitaan dengan sabun pembersih atau sabun sirih. perilaku siswi dalam membuat ramuan tradisional untuk menjaga kesehatan reproduksi menunjukkan hasil yang kurang baik. Lebih dari 70\% siswi MTs dan 96\% siswi MA Habiburrahman tidak pernah membuat ramuan tradisional guna menjaga kesehatan reproduksi kewanitaan.
\end{abstract}

Kata Kunci: Kesehatan Reproduksi, Remaja, Ramuan Tradisional

\section{PENDAHULUAN}

MTs. dan MA. Habiburrahman merupakan salah satu lembaga pendidikan tingkat pertama dan tingkat atas di bawah Departemen Agama yang berada di Desa Jatian, Kecamatan Pakusari Jember. MTs. dan MA. Habibirrahman juga memiliki lembaga pendidikan agama yaitu Pondok Pesantren Habibirrahman. Hampir 90 \% siswa dan siswi MTs. dan MA. Habiburrahman adalah santri pondok. Siswa ditingkat MTs. dan MA. memiliki rentang usia 13-17 tahun yang tergolong usia remaja. Hurlock (1973) memberi batasan masa remaja berdasarkan usia kronologis, yaitu antara 13 hingga 18 tahun. Lebih lanjut Thornburg (1982) membagi usia remaja menjadi tiga kelompok, yaitu: 1) remaja awal antara 11 hingga 13 tahun, 2) remaja pertengahan antara 14 hingga 16 tahun,dan 3) remaja akhir antara 17 hingga 19 tahun.

Siswi MTs. dan MA. Habiburrahman Desa Jatian Pakusari Jember merupakan siswi yang bersetatus sebagai siswi dan santri di Pondok Pesantren Habiburrahman Desa Jatian Pakusari Jember. Kondisi latar belakang ekonomi dan keluarga Siswi MTs. dan MA. Habiburrahman saat ini sebagian besar menggambarkan kelompok status 
ekonomi menengah ke bawah dengan latar belakang pendidikan orang tua juga rendah. Hal ini yang menyebabkan tingkat pemahaman siswi tentang kesehatan reproduksi masih rendah. Selain itu, di lingkungan Pondok Pesantren, mereka terbiasa mandi, tidur dan menggunakan perlengkapan sehari-hari secara bersama-sama dan bergantian, sehingga dapat membuat para siswi/santri kurang menjaga kebersihan dan kesehatan terutama kesehatan reproduksi. Hal ini dapat memudahkan bakteri atau virus menyebar dan berpindah dari satu orang ke orang lain.

Penyebaran informasi mengenai bagaimana menjaga kesehatan rproduksi remaja masih sangat dibutuhkan, karena selama ini seluk beluk kesehatan reproduksi masih belum cukup dipahami baik oleh orang dewasa maupun remaja sendiri. Banyak orang dewasa seperti orang tua, guru, dan tokoh pemuda tidak siap membantu remaja menghadapi masa pubertas. Akibatnya remaja tidak memiliki cukup pengetahuan dan ketrampilan untuk menghadapi berbagai perubahan, gejolak, dan masalah yang sering timbul pada masa remaja. Mereka kemudian terjebak dalam masalah fisik, psikologis, dan emosional yang kadang-kadang sangat merugikan seperti stres dan depresi, penyakit dan infeksi menular, dan lain-lain. Hal ini sebetulnya tidak perlu terjadi bila mereka lebih memahami berbagai proses perubahan yang akan terjadi pada dirinya sehingga lebih siap menghadapi persoalan pubertas dan kesehatan reproduksi (Abdurrahman, 2003). Salah satu masalah pada kesehatan reproduksi untuk wanita adalah gangguan pada sistem reproduksi.

Gangguan pada alat reproduksi wanita dapat berupa keputihan, gangguan menstruasi, kanker rahim, kista, polip dan lain-lain. Salah satu dari jenis gangguan yang lebih sering terjadi di masyarakat adalah keputihan. Pengertian umum dari keputihan yaitu penyakit kelamin pada perempuan (vagina) di mana terdapat cairan berwarna putih kekuningan atau putih kekelabuan baik encer maupun kental, berbau tidak sedap dan bisa menyebabkan rasa gatal. Penyakit gangguan alat reproduksi wanita ini bisa diakibatkan oleh beberapa hal, yaitu jamur, bakteri, virus dan parasit.

Salah satu upaya dalam mengatasi dan mencegah penyakit yang dapat diakibatkan gangguan alat reproduksi adalah melakukan pola hidup bersih dan sehat, serta melakukan perawatan kesehatan reproduksi menggunakan ramuan tradisional, sehingga tidak menimbulkan efek samping. Dengan demikian, perlu dilakukan edukasi dan pelatihan dalam upaya menjaga kesehatan reproduksi remaja menggunakan ramuan tradisional, agar siswi dapat menjaga kesehatan sejak dini.

\section{METODOLOGI PELAKSANAAN}

\section{A. Kerangka Pemecahan Masalah}

Kerangka berpikir untuk memecahkan masalah kegiatan ini digambarkan seperti pada gambar 1. Dari permasalahan yang muncul disusun alternatife untuk memecahkan masalah. Selanjutnya dari berbagai alternative, dipilih alternatif yang paling mungkin dilaksanakan.

\section{B. Realisasi Pemecahan Masalah}


Kegiatan ceramah dan diskusi dilakukan untuk memberikan pemahaman peserta tentang hidup bersih dan sehat, serta mejaga kesehatan reproduksi remaja. Materi ini akan diberikan oleh staf dosen Akademi Farmasi Jember. Materi yang diberikan memuat beberapa hal seperti: apa itu hidup bersih dan sehat, bagaimana menjaga hidup bersih dan sehat, apa itu kesehatan reproduksi, dan bagaimana menjaga kesehatan reproduksi.

b. Praktek

Kegiatan ini merupakan lanjutan dari ceramah dan diskusi yang secara khusus bertujuan untuk meningkatkan kemampuan siswi MTs. dan MA. Habiburrahman dalam hal pengetahuan peserta tentang bagaimana membuat ramuan tradisional untuk menjaga kesehatan reproduksi. Kegiatan ini diisi dengan pelatihan pembuatan ramuan tradisional untuk menjaga kesehatan reproduksi. Kegiatan ini dibimbing oleh staf dosen Akademi Farmasi Jember.

\section{Keterkaitan}

Kegiatan Pengabdian kepada Masyarakat ini melibatkan instansi Akademi Farmasi Jember dan MTs, serta MA. Habiburrahman Desa Jatian Pakusari Jember. Kedua instansi yang terlibat ini mendapat keuntungan secara bersama-sama.

a. MTs. dan MA. Habiburrahman Desa Jatian Pakusari Jember sebagai tempat pelaksanaan kegiatan akan menyediakan SDM berupa siswi PKK yang akan dilatih. Dalam hal ini, MTs. dan MA. Habiburrahman Desa Jatian Pakusari Jember akan memperoleh manfaat dalam hal peningkatan SDM, terutama dalam hal pengetahuan siswi.

b. Akademi Farmasi Jember melalui lembaga Penelitian dan Pengabdian kepada Masyarakat berperan menyediakan dana, sehingga mendukung pelaksanaan dharma ketiga dari tri Dharma Perguruan Tinggi.

\section{Khalayak Sasaran}

Khalayak yang dijadikan sasaran kegiatan ini adalah siswi MTs. dan MA. Habiburrahman Desa Jatian Pakusari Jember. Keterlibatan mereka dalam kegiatan pengabdian kepada masyarakat ini dapat dilihat pada table 1.

\begin{tabular}{|c|c|c|}
\hline Khalayak & Kegiatan & Sasaran \\
\hline $\begin{array}{l}\text { Siswi MTs. dan MA. Habibur } \\
\text { rahman Desa Jatian Pakusar } \\
\text { Jember }\end{array}$ & $\begin{array}{l}\text { Ceramah dan diskusi tentang } \\
\text { ipengetahuan tentang hidup bersih } \\
\text { dan sehat. } \\
\text { Ceramah dan diskusi tentang } \\
\text { pengetahuan tentang menjaga } \\
\text { kesehatan reproduksi. } \\
\text { Praktek tentang pembuatan } \\
\text { ramuan tradisional untuk } \\
\text { kesehatan reproduksi. }\end{array}$ & $\begin{array}{l}\text { Meningkatkan pemahaman } \\
\text { tentang cara hidup bersih dan } \\
\text { sehat, serta menjaga kesehatan } \\
\text { reproduksi remaja }\end{array}$ \\
\hline
\end{tabular}

Tabel 1 Keterlibatan Khalayak Sasaran 


\section{E. Rancangan Evaluasi}

a. Prosedur dan Alat Evaluasi

Untuk mengetahui apakah program yang akan dilaksanakan ini berdampak positif atau sejauh mana program ini terlaksana, sudah barang tentu dibuat suatu evaluasi yang meliput:

Dilakukan pre test mengenai pengetahuan tentang cara hidup bersih dan sehat, serta menjaga kesehatan reproduksi remaja ini dilakukan sebelum kegiatan dilakukan dan untuk mengetahui seberapa besar pengetahuan siswi MTs. dan MA. Habiburrahman tentang tentang cara hidup bersih dan sehat, serta menjaga kesehatan reproduksi remaja

Dilakukan pos test mengenai pengetahuan tentang cara hidup bersih dan sehat, serta menjaga kesehatan reproduksi remaja, materi yang diberikan menyangkut apa yang diinformasikan saat ceramah, tanya jawab maupun diskusi

- Selanjutnya dibandingkan antara skor pre test dan post test, sehingga akan dapat dilihat keberhasilan program yang dilakukan.

Praktek membuat ramuan tradisional

b. Teknik Analisis Data dan Kriteria Keberhasilan Program

Data hasil tes baik pre-test maupun post-test tentang pemahaman cara hidup bersih dan sehat, serta menjaga kesehatan reproduksi remaja dianalisis dengan teknik analisis dekriptif.

\section{HASIL DAN PEMBAHASAN}

A. Pengetahuan Siswi tentang Cara Menjaga Kesehatan Reproduksi

Berdasarkan hasil pengabdian yang telah dilakukan, didapatkan bahwa pengetahuan siswi MTs dan MA Habiburrahman tentang cara menjaga kesehatan reproduksi berada dalam kategori yang sangat baik. Hal ini didukung oleh hasil tes yang diberikan, menunjukkan nilai diatas 85 sesuai gambar 2 dibawah ini.

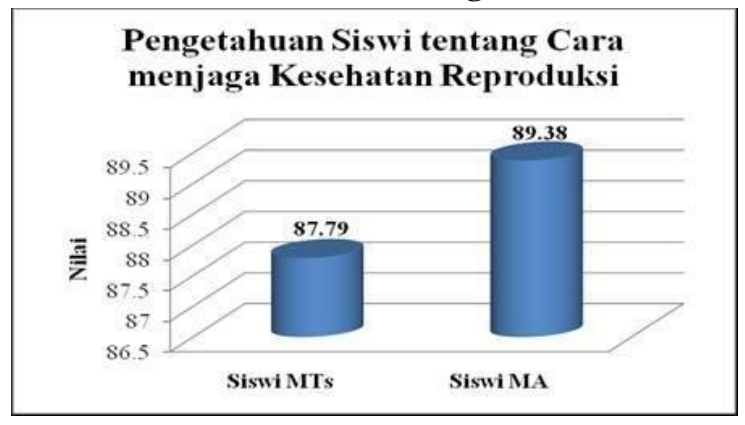

Gambar 2. Pengetahuan siswi tentang cara menjaga kesehatan reproduksi

Hasil diatas juga menunjukkan pengetahuan siswi MA relatif lebih baik dibandingkan siswi MTs. Hal ini dapat disebabkan oleh faktor usia, tingkat pendidikan, dan pergaulan. Siswi MA dengan tingkat pendidikan lebih tinggi dibandingkan siswi MTs, memiliki wawasan yang lebih luas, serta dapat menerima informasi yang lebih banyak dari berbagai media tentang cara menjaga kesehatan reproduksi. 


\section{B. Perilaku Siswi Tentang Pemakaian Sabun Sirih/Sabun Pembersih}

Ditinjau dari perilaku siswi terhadap pemakain sabun pembersih atau sabun sirih untuk membersihkan daerah kewanitaan menunjukkan hasil yang kurang baik. Sebanyak 22 orang siswi MA dan 24 siswi MTs atau sekitar 84\% siswi MA dan 46\% siswi MTs tidak pernah membersihkan daerah kewanitaan dengan sabun pembersih atau sabun sirih, seperti ditunjukkan pada gambar 3. Hal ini dapat disebabkan kebiasaan siswi membersihkan daerah kewanitaan dengan sabun mandi biasa dan tidak menggunakan sabun pembersih khusus daerah kewanitaan. Di sisi lain, pengetahuan siswi MA yang lebih baik, belum mencerminkan perilaku dalam membersihkan daerah kewanitaan dengan sabun pembersih. Dengan demikian, dibutuhkan edukasi dan pendampingan lebih untuk membuat siswi berperilaku yang baik dalm menjaga kesehatan reproduksi.

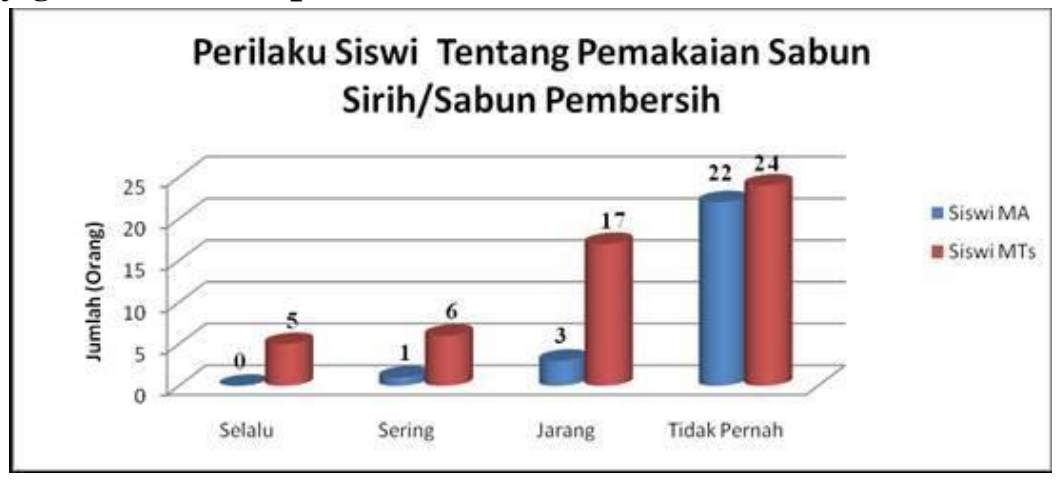

Gambar 3. Perilaku siswi tentang pemakaian sabun sirih/sabun pembersih

\section{Perilaku Siswi Tentang Membuat Ramuan Tradisional}

Dilain pihak, perilaku siswi dalam membuat ramuan tradisional untuk menjaga kesehatan reproduksi menunjukkan hasil yang kurang baik. Lebih dari 70\% siswi MTs dan 96\% siswi MA Habiburrahman tidak pernah membuat ramuan tradisional guna menjaga kesehatan reproduksi kewanitaan, seperti ditunjukkan pada gambar 4.

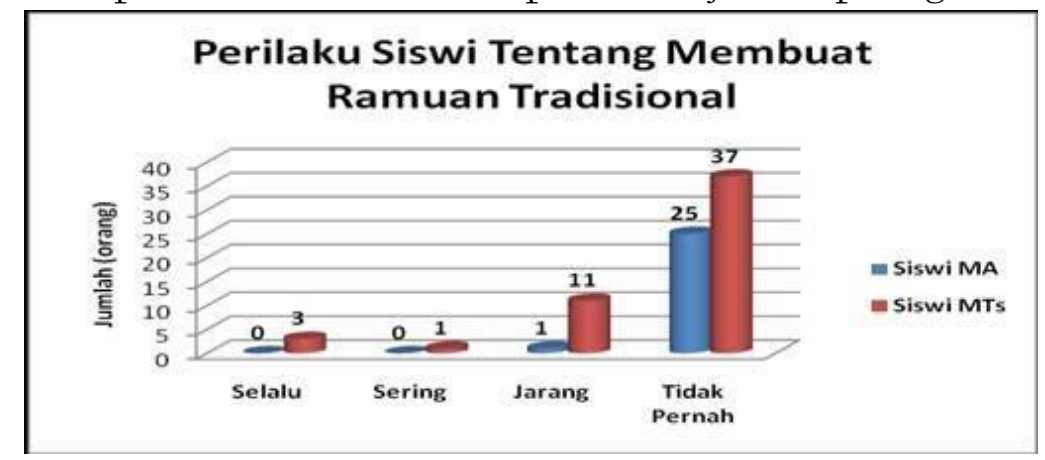

Gambar 4. Perilaku siswi tentang membuat ramuan tradisional

Hal tersebut dapat dikarenakanlingkungan mereka yang ada di dalamlingkungan pondok pesantren, sehingga tidak dapat membuat atau membeli bahan-bahan ramuan tradisional dan didukung dengan peralatan yang kurang memadai di lingkungan. Selain 
itu, perhatian orang tua dan guru dalam menjaga dan mengedukasi siswi MTs dan MA. Habiburrahman masih relative kurang.

\section{PENUTUP}

\section{A. Kesimpulan}

Berdasarkan hasil pengabdian kepada masayarakat yang telah dilakukan, dapat diambil beberapa kesimpulan, antara lain: (1) Pengetahuan siswi menjadi lebih baik, setelah diberikan edukasi tentang cara menjaga kesehatan reproduksi dan (2) Perilaku siswi dilihat dari penggunaan sabun permbersih dan pembuatan ramuan tradisional untuk menjaga kesehatan reproduksi masih kurang.

\section{B. Saran}

Perlu ada tindak lanjut, dan monitoring perilaku siswi terhadap cara menjaga kesehatan reproduksi, khususnya dengan ramuan tradisional

\section{Ucapan Terimakasih}

Ucapan terimakasih penulis ucapkan kepada semua pihak yang telah membantu dalam kegiatan pengabdian kepada masyarakat ini, sehingga kegiatan dapat terlaksana dengan baik, terutama kepada:

1) Direktur Akademi Farmasi Jember

2) Ketua LPPM Akademi Farmasi Jember

3) Ketua Program studi Diploma III Farmasi Akademi Farmasi Jember

4) Pengasuh pondok pesantren Habiburrahman Jatian-Pakusari

5) MTs. dan MA. Habiburrahman Jatian-Pakusari

6) Pihak-pihak lain yang telah membantu.

Semoga artikel ini dapat bermanfaat bagi penulis dan pembaca.

\section{DAFTAR PUSTAKA}

Abdurrahman, Mulyono. 2003. Pendidikan bagi Anak Berkesulitan Belajar. Jakarta. Rineka Cipta.

Hurlock, B.E. 1973. Psikologi Perkembangan Anak. Jakarta. Erlangga

Thornburg, D.H. 1982. Development an adolescence Second Edition. California. Brook Cole Publishing co. 


\section{DOKUMENTASI KEGIATAN}
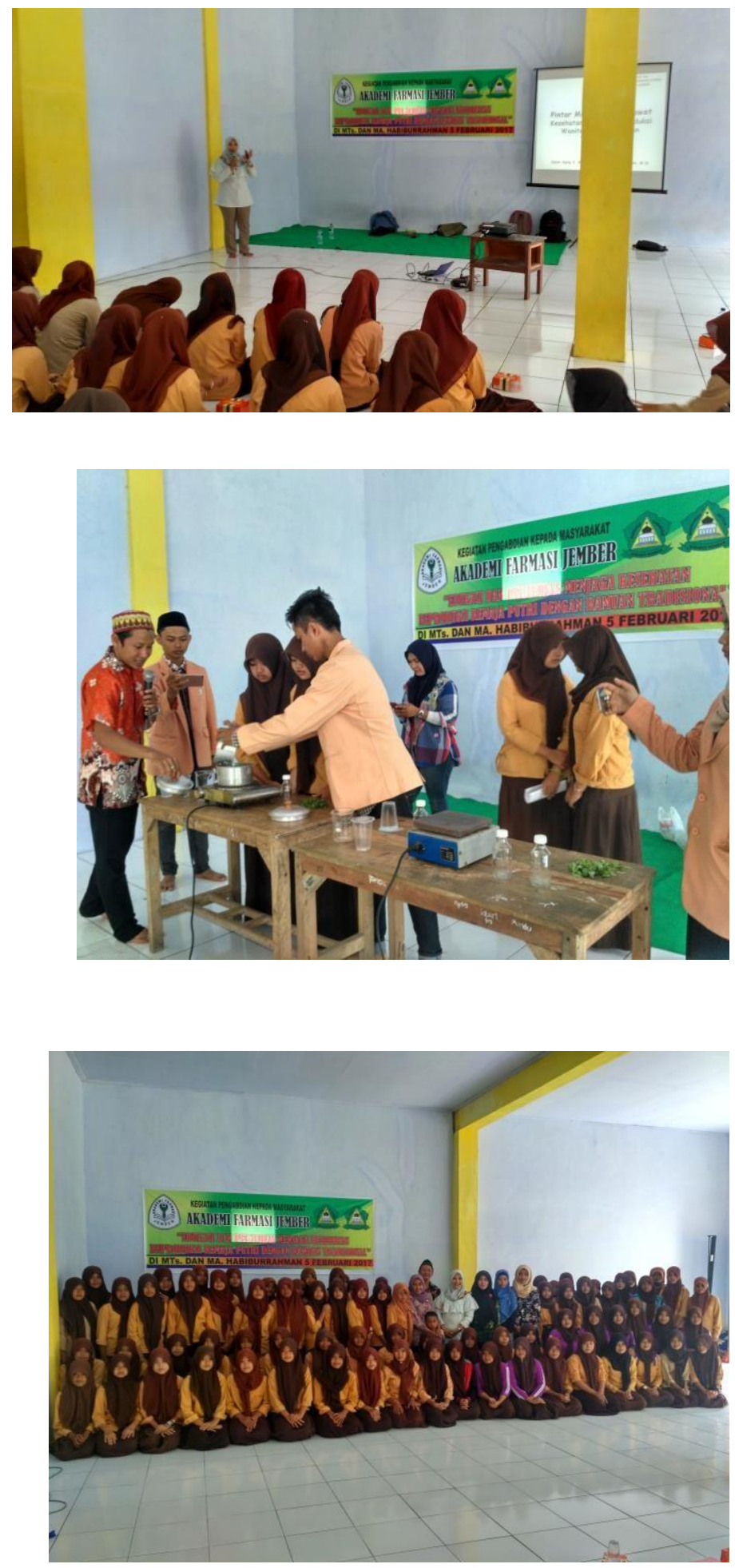


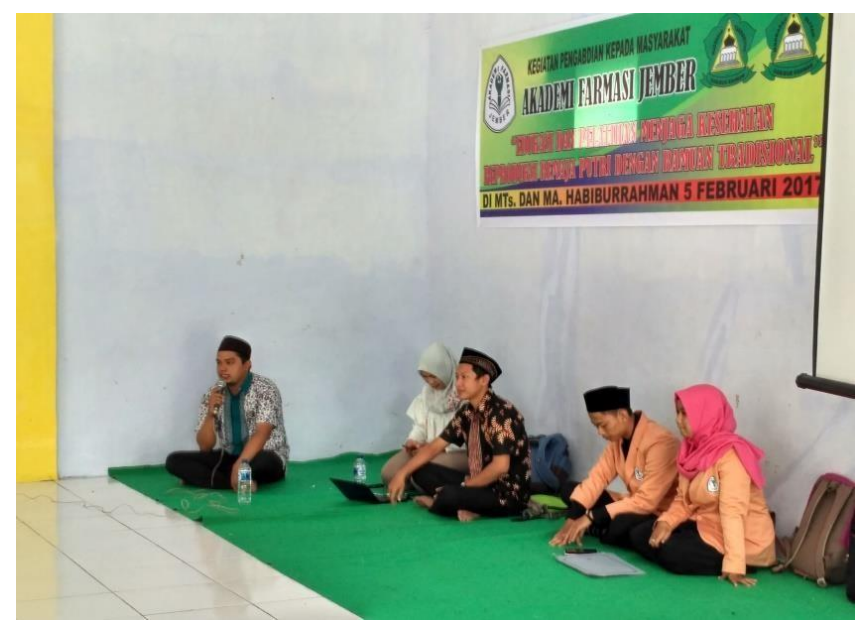

